\title{
The Reality of Using Electronic Learning Applications in Education by the Science Teachers in the Schools of A-Tafilah Governorate
}

\author{
Nusaibah Muhmmad Al-Muhasen \\ Tafila Technical University, Tafila, Jordan \\ P.O.Box 179 Jordan -Tafila
}

Received: August 1, 2017 Accepted: Sep. 28, $2017 \quad$ Published: November 1, 2017

doi:10.5296/jse.v7i4.11556 URL: https://doi.org/10.5296/jse.v7i4.11556

\begin{abstract}
This study addressed the reality of using e-learning applications in teaching science at Tafila schools. It also sought to identify the attitudes of science teachers at Tafila schools towards e-learning applications and the obstacles they encounter when using them. The study employed a descriptive methodology to achieve its objectives. The sample consists of (197) teachers from public schools in Tafila Directorate of Education. The findings of the study showed that the majority of the sample members sufficiently use e-learning applications despite their weak or negative attitudes towards them. No statistical difference was found in the teachers application of e- learning Attributable to teachers gender, teacher experience and education. In additional, The study found that the lack of personal computers at schools was considered the major obstacle teachers face. Accordingly, the study recommended offering more financial and spiritual incentives to teachers, increasing the financial support devoted to e-learning and staffing schools with technicians as well as computer experts to help teachers use e-learning applications.
\end{abstract}

Keywords: e-learning, applications, science teachers, Al-Tafila. 


\section{Introduction}

Nowadays, the world is witnessing a considerable technological and scientific revolution that has a great impact on all the aspects of life; it contributed to creating a large civilized leap and turned the world into a small electronic village, and so the distance became nearer and subsequently there are no more temporal and spatial boundaries between the individuals in the one society or the various societies, as everyone can use its techniques and recognize the different domains relating to it. The scientific revolution tools became a necessity and represent a scale for the extent of advancement of the society. The scientific technology entered the educational process largely, affected its reality and played an important role in the educational process due to its characteristics that are reflected positively on both the learner and the teacher. Thus, incorporating technology in the teaching process became an urgent demand.

Using the electronic learning with its complete system in the educational environment became an important and necessary demand prompted by the need to the qualitative development needed for the scientific content of the curricula and the academic courses as well as the teaching methods needed for the activation and the enrichment of the educational environment with appropriate techniques, methods and data. The importance of building effective educational components led to the importance of adopting an educational strategy that lead practically to educational data of a high level that qualify the learner to graduated students to face the conflicts of practical life as well as the future scientific development effectively (Al-Mosawi, 2008).

Those who are responsible for the educational system in the world realized early the importance of the teacher role. and thus they took into consideration providing all the necessary potentials to prepare the teacher and qualify him educationally, behaviorally and professionally, since the profession of teaching doesn't only depend on talent and practice, but also on mastering the rules and methods that are based on scientific bases derived from the educational and psychological theories in addition to the training that they take pre-service. the researches show that most of the programs available regarding the preparation of teachers in the Arab countries share the same model that has an academictechnological trend which focuses on the skills and techniques of teaching (Qotait, 2011).

In order to prepare a generation that is able to accommodate the changes that were created by the revolution of technology of information and communication, the ministry of education in many Arab countries sought to establish the national strategies in order to merge the information technology within the educational system; it trained teachers and prepared the schools with the suitable computer laboratories, and were interested in providing the demands relating to computer as an educational method, in a manner that serves the different academic subjects. However, the results of assessing these projects which reached to hundreds of millions of Jordanian dinars showed that even though there are programs for constructing the educational capabilities at schools, most of the teachers' practices in the classroom remained distant from using the technology of information and technology and so the established plans didn't meet the real objectives (Al-Na'washi, 2010). 
The educators were encouraged to use the electronic networks in the process of teaching, given the availability of the information resources, including encyclopedias and data bases, as well as the direct communication using the auditory techniques, the written form, images as well as the indirect communication via the e-mail and the voice mail (Al- Kindari, Al-Rashidi, and AbdulRaheem, 2011).

The problem of the study and its importance:

Many countries introduced the modern technology as well as the internet in teaching science and many of the Arab countries started to make use of these techniques. Bill Gates, the general manager of Microsoft company, commented by saying that the rapid method of communication will contribute to raising the educational criteria for each individual in the coming generation and will give the way for the emergence of new ways for teaching as well as a broader range for selection, and the learning that uses the applications of e-learning will represent the start point towards the continuous learning, and the good teachers in the future will do more than educating the students about the way how to find information, as they will need to know when to test and when to teach or to evoke the interests (Ayyash, and Al-Safi, 2007).

The great and rapid evolution that the world is witnessing in the methods of communication and scientific innovations as well as the age of science and technology where we currently live, in addition to the development of the science of space, communication, computer, engineering, medicine, heredity, as well as the science of genetics, and the bio reproduction ...made it necessary to reconsider all the methods of teaching as well as reconsidering the curriculum and the academic subjects that were exposed to development, change and additions. Therefore, the educators found themselves infront of a new challenge and a necessity of coping with this rapid development as well as developing the methods of teaching science at our schools in order to cope with the scientific evolution that the world is witnessing (Sobaitan, 2010)

In order to know the extent of success in the plans of education regarding the e- learning we must evaluate what have been achieved in order to recognize the positive points and support them and to avoid the negative points by releasing their causes which, in turn, will contribute to employ the efforts, powers and money in a way that achieves the objectives relating to the plans and educational programs in terms of creating a better environment of E-learning before adapting it on a large scale (Al-Shonaq and BaniDomi, 2009).

E-learning has changed the traditional roles of teachers. The role of the teacher in e-learning has become related to designing the educational content, designing the e-learning programs as well as evaluating the students. The activation of e-learning depends on the degree to which science teachers use e-learning applications in science education. Hence, the present study seeks to know the reality of the using e-learning applications among the science teachers in Al-Tafila governorate and the obstacles facing the application of e-learning. The problem of the study lies in answering the following questions: 
1. What is the extent at which science teachers use e-learning applications in teaching science in Al-Tafila from their perspective?

2. What are the attitudes of science teachers towards e-learning applications?

3. What are the obstacles facing the science teachers in using e-learning applications in teaching science in Al-Tafila governorate from their point of view?

4. Does the degree to which science teachers use e-learning applications differ by gender, experience, and qualification?

5. Do the obstacles of using e-learning applications among science teachers differ according to gender, experience and qualification?

The importance of this study lies in the importance of e-learning in general and teaching science in particular, where the Hashemite Kingdom of Jordan seeks to educate the members of the society and prepare them to face global and local changes and challenges in which the e-learning is centered around the learner and makes him as its ultimate goal and thus he shoulders a great deal of responsibility in terms of his education and self-efficacy. The importance of the study lies in identifying the reality of using the applications of e-learning among the science teachers in teaching science as well as identifying their attitudes towards it. This study can be seen as beneficial for those who are in charge of preparing the teachers' programs in the faculties of education to focus on e-learning applications within the requirements of educational preparation for teachers and how to use them in the educational process. In the light of the study results, we can conclude the most important impediments that challenge using the applications of e-learning in teaching science which, in turn, represents an important step in finding the suitable solutions for that as well as identifying the teachers' attitudes towards using the applications of e-learning and promoting their attitudes towards positivism as well as concluding the results, recommendations, and suggestions that could contribute to developing and improving science teaching.

The terminology of the study:

The Science teachers: male and female teachers who teach general sciences, physics, chemistry, biology, Geology for the primary and secondary stages in Al-Tafila governorate for the academic year (2015/2016).

E-Learning Applications: in the current study, they refer to the types of programs, sites and electronic sources of information, including computers, networks, multimedia, electronic libraries, Internet portals, e-mail, compact discs and social networking sites that can be used in teaching science.

The reality of usage: in the current study, it refers to the degree at which the science teachers use e-learning applications in the educational practices and the obstacles that prevent using e-learning applications in science teaching and their attitudes towards them as measured by the teachers' response to the tool prepared for this purpose. 
Obstacles: the causes that minimize or affect negatively on the degree at which the science teachers use e-learning applications in teaching science. They are measured procedurally by the response of teachers to the items of the questionnaire prepared for this purpose.

The attitudes towards e-learning: The amount of emotional distress manifested by the study sample individuals regarding e-learning, represented by acceptance, rejection, or hesitation. The attitude towards e-learning is procedurally measured by the degree of the teachers in response to the items of the questionnaire prepared for this description.

The previous studies:

Al-Amayra, (2003) conducted a study that aimed at identifying the opinions of some teachers in the schools of the International Relief Agency / Jordan regarding the importance of using educational technology in teaching, and the difficulties that face them in using it as well as identifying if the following variables: gender, teaching experience, specialization, and scientific qualification as well as the stage in which the teacher teaches have an impact on the perspective of the teachers regarding the importance of using the educational techniques in teaching. The study sample consisted of 151 male and female teachers who work in 24 primary and preparatory schools. the results showed that there are no statistically significant differences regarding the impact of the variables on the degree at which the science teachers use e-learning applications in teaching, while the results showed that there are statistically significant differences in the impact of the stage, in which the teacher teaches, on the degree at which the science teachers use e-learning applications in teaching, and for the benefit of the teachers in the preparatory stage.

Hudson, Porter, Nelson (2008) conducted a study which aimed to identify the difficulties that face using information and communication technology in teaching mathematics in the high schools in the state of New South Wales (Australia). The study sample consisted of (114) Mathematics teachers who agreed previously to participate in the study. The questionnaire was distributed by the mail. The most important results of the study implied that the difficulties in using information and communication technology in teaching mathematics could be summarized as follows: $72 \%$ of the teachers believed that the inability to access to computer laboratories prevented them from using computer in teaching mathematics; (64\%) believed that the difficulty of accessing to computers prevents them from using computers in teaching mathematics; $(63 \%)$ believed that the absence of study plans for the lessons directed towards the use of computers in the teaching of mathematics prevented them from using the computer in teaching mathematics, and $(60 \%)$ believed that the lack of time for training prevented them from using computers in teaching mathematics.

Al-Shonaq and BaniDomi, (2010) conducted a study that aimed at identifying the attitudes of both teachers and students towards using the e-learning in teaching science. The study sample consisted of 28 male and female teachers from those who teach computerized physics for the first secondary class as well as 118 students distributed to five groups in three secondary schools for boys ; four groups were experimental and were taught by using the (internet, combat discs, or by a teacher who uses data show), while the control group used the usual way of teaching. The results showed that there are positive attitudes among the teachers toward 
using the e-learning, where the total mean for the estimation of teachers on the scale of the attitudes towards e-learning was (3.76) out of (5) and that there was a statistically significant negative impact regarding the students' attitudes, where the mean of the students' attitudes before the experiment was (3.78), which is higher than that after the experiment (3.33).

Al-kindari, Al-Rashidi and AbdulRaheem, (2011) conducted a study that aimed at identifying the most important objectives and advantages of e-learning as well as identifying the nature of the obstacles that prevent applying the e-learning in the curricula of the preparatory stage in Kuwait from the perspective of Arabic language teachers. The study used the descriptive approach in order to achieve its objectives. The study sample consisted of 300 male and female Arabic language teachers from the educational regions in Kuwait. the study concluded that there are a number of obstacles that prevent the application of e-learning in the curricula of the preparatory stage in Kuwait, where the human obstacles were in the first place, followed by the financial and material obstacles (such as fear from the transfer from the traditional way of teaching to the e-learning as well as the lack of awareness regarding the culture of e-learning and its objectives in the educational process, in addition to the insufficient time for introducing all the needed material electronically, the lack of depth in the subject, which reduces the interaction between the teacher and the student, the lack of the logical organization of the information introduced via the internet, and the difficulty of introducing some curricula using the e-learning.

(Al-Kasasbeh 2012) conducted a study which aimed to identify using e-learning applications in teaching science among science teachers as well as identifying the obstacles that prevent applying the e-learning in the schools of Al-Karakdistrict. The study sample consisted of (238) male and female teachers who are teaching the subjects of science. The results of the study showed that the degree of using e-learning applications was medium, and that the obstacles of using e-learning applications among the science teachers were generally medium.

(Murad, 2012) conducted a study which aimed to identify the degree at which a sample of male and female teachers in the educational directorate of Al-Shoubak know the basic programs and applications for communication and information technology as well as identifying the degree of using them in the subjects that they are teaching and identifying the obstacles that prevent applying the e-learning applications. The study sample consisted of (101) male and female teachers who were chosen randomly from the different schools in the district of Al-Shoubak. The results of the study showed that the majority of the sample individuals use the programs and applications for communication and information technology sufficiently, but they use them slightly for the purposes of teaching. The results also showed there are some obstacles that prevent applying the programs and applications for communication and information technology to teaching, including the lack of equipments and infrastructure as well as the lack of training of using the programs and applications for communication and information technology in teaching. 


\section{The method and procedures}

The study sample and population

The study population consisted of all the male and female teachers who teach the subjects of general science and biology, chemistry, physics and geology in Al-Tafila governorate for the academic year 2015/2016 with a total of 197 male and female teachers during the second semester of the academic year 2015/2016 according to the statistics of the Directorate of Education in Al-Tafila governorate.

The study sample consisted of (177) male and female teachers and table 1 shows the distribution of the study sample individuals according to the levels of variables, a reliability sample of (20) male and female teachers was selected and it wasn't a part of the study sample.

Table 1. Describing the traits of the study sample based on its variables

variable

categories

Diploma

Bachelor

Postgraduate

Total

Experience

Gender
Less than 5 years

10-5

More than 10 years

Total

Male

Female

Total
Number

\section{7}

145

25

177

40

70

67

177

84

93

177
Percentage

$\% 4.0$

$81.9 \%$

$\% 14.1$

$\% 100.0$

$\% 22.6$

$\% 39.5$

$\% 37.9$

$\% 100.0$

$\% 47.5$

$52.2 \%$

$100 \%$

The procedures:

1- The study tool was prepared in its initial form and its validity and reliability were verified using the scientifically known methods by presenting them to a group of experienced and competent arbitrators, and then developing the study tool in its initial form. During 0ctober 2015

2 - The number of male and female science teachers was limited in order to determine the study population and sample as well as the exploratory sample after obtaining the approval of the Directorate of Education in Al-Tafileh governorate based on appeal from the presidency of Mu'tah University. During December 2015. 
3 - Applying the study tool to the exploratory sample individuals in order to show the psychometric characteristics which consisted of (20) characteristics in 2/2/2016

4. Applying the study tool to the sample individuals, where the researcher visited the restricted schools and talked to the school headmasters as well as the science teachers about the study objectives and then distributed the questionnaire to the science teachers. During February 2016.

5. After the personal pursuing by the researcher, the questionnaires were collected; and the process of distributing and returning the questionnaires took three weeks. During February 2016.The number of distributed questionnaires was (197) questionnaires and all of them were returned because the researcher was waiting in the school until the teacher ended. Or she went to one of the adjacent schools until they finish.

6 - Collecting the questionnaires, and conducting appropriate statistical processes regarding the collected data.

7- Presenting the results and discussing them in order to answer the study questions and cite the recommendations.

The study tools

The researcher prepared the study tool (questionnaire) based on the following methodological procedures:

1 - Reviewing the theoretical literature and the previous studies related to the subject of the study.

2 - Preparing the items of the (questionnaire) to measure the reality of the degree at which science teachers use e-learning applications and identifying the obstacles that prevent them from using these applications as well as their attitudes towards that. The questionnaire consisted of two parts:

The first part: the general data related to the individuals of the study sample regarding educational qualifications, major, gender, computer literacy and teaching experience.

The second part: it consists of three sections:

The first section: The uses of science teachers for e-learning applications: It consisted of five domains where the scale was used to measure the degree of using ranged as (very much, much, medium, little, very little).

The first domain: computer programs, which consisted of 7 items.

The second domain: electronic devices, which consisted of 6 items.

The third domain: web 1 applications, which consisted of 11 items.

The fourth domain: web 2 applications, which consisted of 7 items.

The fifth domain: the strategies of e-learning, which consisted of 6 items. 
The second sections: The attitudes of science teachers toward e-learning applications ; it consisted of (29) items. The five-point Likerts scale was used as follows:

(extremely agree, agree, neutral, disagree, extremely disagree).

The third section: the obstacles of using e-learning applications which ranged as (very much, much, medium, little, very little) and consisted of four domains:

First: the obstacles relating to the e-learning, and consisted of 7 items.

Second: the obstacles relating to the technical and administrative aspects, which consisted of 10 items.

Third: the obstacles relating to the teacher, and consisted of 9 items.

Fourth: the obstacles relating to the student, and consisted of 7 items.

Using the e-learning applications was classified into three levels (low, medium, and high) according to the means of the respondents for each item as follows:

The category length $=$ the highest degree $(5)$ - the lowest degree $(1) \div 3=1.33$

(3) is the number of levels.

And so the levels would be as follows:

1- The mean that ranges between (1-2.33) is considered weak.

2- The mean that ranges between (2.34- 3.67) is considered medium.

3- The mean that ranges between (3.68-5) is considered high.

As for the attitudes, given that the neutral response is equal to 3, the researcher considered that those who scored less than 3 would have a negative attitude and that those who scored more than 3 would have a positive attitude.

\section{The study design}

The results

The results relating to the first question "what is the degree at which the science teachers in Al-Tafila governorate use the e-learning applications in teaching science from their perspective?"and discussing them.

In order to answer this question, the means and the standard deviations were calculated for the responses of the sample individuals according to each domain of the study

domains as well as the total domain and table (2) illustrate the results. 
Table 2. the means and the standard deviations for the degree at which the science teachers use the e-learning applications

\begin{tabular}{lllll}
\hline Rank & domains & mean & Standard deviation & level \\
\hline 1 & E - learning strategies & 3.94 & 1.18 & High \\
& & & & \\
2 & electronic devices & 3.76 & 0.95 & High \\
3 & Web 1 applications & 3.59 & 0.99 & Medium \\
4 & Web 2 applications & 3.45 & 0.98 & Medium \\
5 & Computer Programs & 3.12 & 0.91 & Medium \\
& & & & \\
- & Total & 3.56 & 0.81 & Medium \\
\hline
\end{tabular}

Table (2) illustrates that the means regarding the level at which the science teachers in Al-Tafila governorate use the e-learning applications in teaching science was of a medium degree and a mean of (3.56) and a standard deviation of (0.81). as for the level of the domains, E - learning strategies were in the first place with a high degree and a mean of (3.94); the electronic devices were in the second rank with a mean of (3.76) and a high degree; Web 1 applications were in the third rank with a mean of (3.56) and a medium degree; Web 2 applications were in the third rank with a mean of (3.45) and a medium degree; and finally the domain of computer programs was in the last rank with a medium degree and a mean of (3.12). Figure (1) illustrates the variation regarding the levels at which the science teachers use the e-learning applications according to each domain and the total domain.

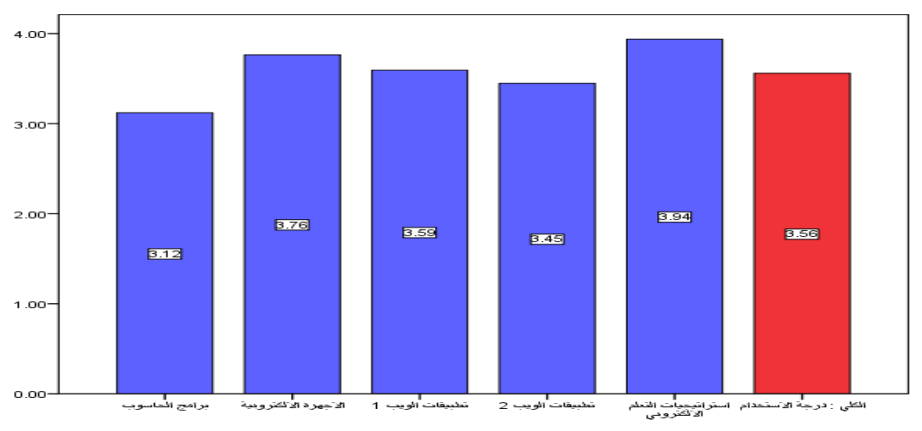

Figure 1. the variation regarding the levels at which the science teachers use the e-learning applications according to each domain

And here is a detailed presentation for the degree at which the science teachers in Al-Tafila governorate use the e-learning applications in teaching science from their perspective according to each domain, and that tables (4), (5), (6), (7), (8) show that:

The first domain: computer programs. 
Table 3. The means and the standard deviations for the domain of computer programs

\begin{tabular}{|c|c|c|c|c|c|}
\hline number & Rank & Theitem content & mean & $\begin{array}{l}\text { Standard } \\
\text { deviation }\end{array}$ & level \\
\hline 1 & 1 & The software of word processor & 3.63 & 1.19 & Medium \\
\hline 3 & 2 & The software of PowerPoint & 3.48 & 1.26 & Medium \\
\hline 2 & 3 & The software of Excel & 3.34 & 1.27 & Medium \\
\hline 7 & 4 & The software of Multimedia & 3.28 & 1.33 & Medium \\
\hline 5 & 5 & $\begin{array}{l}\text { The software of pictures an } \\
\text { drawing, such as Photoshop an } \\
\text { painter }\end{array}$ & $\begin{array}{l}d 3.18 \\
d\end{array}$ & 1.11 & Medium \\
\hline 6 & 6 & The software of computer simulatio & 2.66 & 1.16 & Medium \\
\hline 4 & 7 & The software of Microsoft access & 2.28 & 1.11 & low \\
\hline 1 & - & Total & 3.12 & 0.91 & Medium \\
\hline
\end{tabular}

Table 3 shows that the overall mean for the degree at which the science teachers use the e-learning applications in the domain of computer programs was medium, with a mean of 3.12 and a standard deviation of 0.91 , where all the items were of a medium degree except for the item (7) regarding "Microsoft Access database software" which was low.

This can be attributed to the importance of the advantage provided by the Microsoft Word processor that is beneficial to teachers in the teaching process, where they can prepare clear printed material, and the teacher work that is presented to students is often based on the printed materials such as writing assignments, reports and questions, and this also attributed to the ease of using the software; therefore, using Microsoft word processor was the highest among the e-learning applications. The Power Point software was in the second place, and this can be attributed to the fact that the advantage that is introduced via this software is important in the educational process, where it helps the teacher to introduce the educational material to the students clearly by designing educational presentations as well as simple educational programs that contain text, image and sound, and thus helps the teacher to thrill students and promote their motivation. These two applications gained the highest scores because training the teacher mainly focuses on these two applications more than the others, and they are also considered as the easiest to use. Microsoft Excel is also used because the teachers use it in the educational calendar as well as in the measurement and evaluation processes rather than in teaching. This finding was consistent with the results of (Al-Kasasbeh, 2012), which suggested that the most commonly used application was the Microsoft Word processor with a mean of (3.40).

The second domain: the electronic devices: 
Table 4. he means and the standard deviations for the domain of electronic devices

\begin{tabular}{|c|c|c|c|c|c|}
\hline number & Rank & Item content & mean & $\begin{array}{l}\text { Standard } \\
\text { deviation }\end{array}$ & level \\
\hline 8 & 1 & \multicolumn{2}{|c|}{ Electronic interactive whiteboard 4.16} & 1.21 & High \\
\hline 12 & 2 & \multicolumn{2}{|c|}{ Panel electronic advertisin 4.16} & 1.02 & High \\
\hline 13 & 3 & ers that serve the local Internet & 3.94 & 1.17 & High \\
\hline 11 & 4 & Tablet PC & 3.88 & 1.20 & High \\
\hline 9 & 5 & \multicolumn{2}{|c|}{$\begin{array}{l}\text { Iearning devices such as mobile p3.51 } \\
\text { pad }\end{array}$} & 1.31 & Medium \\
\hline 10 & 6 & Data projector (data show) & 2.94 & 1.37 & Medium \\
\hline- & - & Total & 3.76 & 0.95 & Medium \\
\hline
\end{tabular}

Table 4 shows that the overall mean for the degree at which the science teachers use the e-learning applications in the domain of electronic devices was medium, with a mean of 3.76 and the means ranged between (3.76- 4.16) and a standard deviation of 0.95 , where the items that ranked from (1-4) were of a high degree and the items that ranked from (5-6) were of a medium degree, and thus this finding conflicted with(Al-Kasasbeh, 2012), where the degree of employing them among the science teachers in A-Karak educational district low.

This is due to the ease of availability of these devices at present, such as data show, Ipad, and Mobile learning devices such as mobile phone and I pad such as the mobile phone.

The third domain: Web (1) Applications 
Table 5. the means and the standard deviations for the domain of Web (1) Applications

\begin{tabular}{|c|c|c|c|c|c|}
\hline number & Rank & Item content & mean & $\begin{array}{l}\text { Standard } \\
\text { deviation }\end{array}$ & level \\
\hline 18 & 1 & Science-related educational sites & 3.89 & 1.08 & High \\
\hline 22 & 2 & scientific electronic encyclopedias & 3.88 & 1.22 & High \\
\hline 16 & 3 & E-mail & 3.85 & 1.09 & High \\
\hline 19 & 4 & Scientific databases & 3.80 & 1.05 & High \\
\hline 23 & 5 & Electronic Educational Forums & 3.74 & 1.16 & High \\
\hline 20 & 6 & Scientific journals sites & 3.65 & 3.28 & Medium \\
\hline 17 & 7 & News Groups & 3.50 & 1.19 & Medium \\
\hline 15 & 8 & E-books & 3.46 & 1.22 & Medium \\
\hline 14 & 9 & Electronic Periodicals & 3.44 & 1.25 & Medium \\
\hline 21 & 10 & Chat rooms and dialogue & 3.43 & 1.19 & Medium \\
\hline 24 & 11 & Using audio and video conferences & 2.89 & 1.35 & Medium \\
\hline- & - & Total & 3.59 & 0.99 & Medium \\
\hline
\end{tabular}

Table 5 shows that the overall mean for the degree at which the science teachers use the e-learning applications in the domain of Web (1) Applications was medium, with a mean of 3.59 and a standard deviation of 0.99 , this is due to the increased awareness of male and female teachers as well as having the skills for using it where the items that ranked from (1-5) were of a high degree and the items that ranked from (6-11) were of a medium degree, and thus this finding conflicted with (Al-Kasasbeh, 2012), where the degree of employing them among the science teachers in A-Karak educational district was low.

The fourth domain: Web (2) Applications

Table 6. the means and the standard deviations for the domain of Web (2) Applications

\begin{tabular}{lllccl}
\hline number & Rank & Item content & mean & $\begin{array}{c}\text { Standard } \\
\text { deviation }\end{array}$ & level \\
\hline 27 & 1 & YouTube & 4.14 & 1.12 & High \\
25 & 2 & $\begin{array}{l}\text { Social networking sites face } \\
\text { book }\end{array}$ & 3.86 & 1.30 & High \\
& $\quad$ WhatsApp & 3.81 & 1.14 & High \\
28 & 3 & Social networking sites tweeter & 3.79 & 1.19 & High \\
31 & 4 & Educational Blogs & 3.04 & 1.56 & Medium \\
30 & 5 & Cloud computing software & 2.87 & 1.43 & Medium \\
29 & 7 & Google drive & 2.62 & 1.33 & Medium \\
- & - & Total & 3.45 & 0.98 & Medium \\
\hline
\end{tabular}

Table 6 shows that the overall mean for the degree at which the science teachers use the e-learning applications in the domain of Web (2) Applications was medium, with a mean of 3.45 and a standard deviation of 0.98 , where the items that ranked from (1-4) were of a high 
degree and the items that ranked from (5-7) were of a medium degree; this is attributed to the fact that YouTube launched a special educational channel to disseminate the educational content that takes the form of video clips and every teacher or student can obtain the needed educational lectures using you tube whenever and wherever they and these lectures available at YouTube help teachers during their preparation for lessons in which they can add video clips and exchange ideas and lesson plans with the teachers throughout the world. This finding conflicted with (Al-Kasasbeh, 2012), where the degree of employing them among the science teachers in A-Karak educational district was low.

The fifth domain: using the strategies of e-learning

Table 7. the means and the standard deviations for the domain of using the strategies of e-learning

\begin{tabular}{lllccc}
\hline number & Rank & Item content & mean & $\begin{array}{c}\text { Standard } \\
\text { deviation }\end{array}$ & level \\
\hline 32 & 1 & cognitive Flight - web quest & 4.18 & 1.98 & High \\
33 & 2 & Electronic achievement file & 4.03 & 1.04 & High \\
34 & 3 & Electronic Mind Maps & 4.01 & 1.09 & High \\
36 & 4 & Participatory e-learning & 3.88 & 1.06 & High \\
35 & 5 & Interactive Museum & 3.85 & 1.10 & High \\
37 & 6 & Electronic Educational Bags & 3.69 & 1.15 & High \\
- & - & Total & 3.94 & 1.18 & High \\
\hline
\end{tabular}

Table 7 shows that the overall mean for the degree at which the science teachers use the e-learning applications in the domain of the strategies of e-learning was high, with a mean of 3.94 and a standard deviation of (1.18), where all the items of this domain were of a high degree; this may attributed to the nature of the e-learning in which it helps the teacher to deliver information to the students as well as motivating them via the figures, drawings, images, colors, motion, video clips, and simulation as well as visual and auditory conferences in addition to e-mail, besides including some multimedia within the curricula in a way that helps the teacher to use the strategies of e-learning, and supervisors often focus on the importance of using the e-learning applications, especially in teaching science, and they are considered of the domains that are related to the evaluation of the teacher.

2.1.4 The results relating to the second question "what is the attitudes of the science teachers towards applying the e-learning applications?" and discussing them.

In order to answer this question, the means and the standard deviations were calculated for the responses of the sample individuals according to the scales of attitudes towards implementing the e-learning applications, and table (8) illustrates the results. 
Table 8. the means and standard deviations for the attitudes of teachers towards using E-learning

\begin{tabular}{|c|c|c|c|}
\hline Number & $\mathrm{Ra}$ & Item content & $\begin{array}{r}\text { meanStandard } \\
\text { deviation } \\
\end{array}$ \\
\hline 2 & 1 & I think the internet is necessary for every teacher & 3.561 .28 \\
\hline 1 & 2 & I think the computer is necessary for every teacher & 3.321 .18 \\
\hline 3 & 3 & $\begin{array}{l}\text { I think that using a computers is basic for modern teaching } \\
\text { techniques }\end{array}$ & 3.201 .23 \\
\hline 6 & 4 & $\begin{array}{l}\text { I think that e-learning provides a lot of resources for } \\
\text { teachers }\end{array}$ & 2.981 .31 \\
\hline 4 & 5 & $\begin{array}{l}\text { I think that using the Internet is the foundation of modern } \\
\text { teaching techniques }\end{array}$ & 2.931 .30 \\
\hline 5 & 6 & $\begin{array}{l}\text { I think that e-learning creates a dynamic system that is } \\
\text { affected by the events of the outside world }\end{array}$ & 2.751 .22 \\
\hline 9 & 7 & $\begin{array}{l}\text { I think that e-learning makes it easier to access the } \\
\text { curriculum anytime of the day in all the days of the year }\end{array}$ & 2.461 .16 \\
\hline 12 & 8 & $\begin{array}{l}\text { I think e-learning helps students develop their skills, } \\
\text { knowledge and experience }\end{array}$ & 2.291 .10 \\
\hline 8 & 9 & $\begin{array}{l}\text { I feel that e-learning facilitates the communication process } \\
\text { with the teacher }\end{array}$ & 2.250 .91 \\
\hline 23 & 10 & $\begin{array}{l}\text { I believe that e-learning helps to clarify the scientific } \\
\text { concepts for the students }\end{array}$ & 2.231 .05 \\
\hline 17 & 11 & $\begin{array}{l}\text { I think that using e-learning leads to the development of the } \\
\text { teachers' professional performance }\end{array}$ & 2.161 .14 \\
\hline 24 & 12 & $\begin{array}{l}\text { I think e-learning helps students in learning the scientific } \\
\text { concepts }\end{array}$ & 2.080 .96 \\
\hline 13 & 13 & $\begin{array}{l}\text { I think that e-learning transforms the traditional classroom } \\
\text { image into an interactive learning environment (open) }\end{array}$ & 2.061 .00 \\
\hline 14 & 14 & $\begin{array}{l}\text { I think that e-learning maintains the impact of learning and } \\
\text { makes it memorable in the student's mind }\end{array}$ & 2.020 .97 \\
\hline 22 & 15 & $\begin{array}{l}\text { I think that e-learning helps to connect betweenthe } \\
\text { scientific concepts in a logical way }\end{array}$ & 2.020 .88 \\
\hline 21 & 16 & $\begin{array}{l}\text { I feel happywhen using e-learning applications in science } \\
\text { teaching }\end{array}$ & 2.020 .90 \\
\hline 7 & 17 & $\begin{array}{l}\text { I think e-learning increases the communication between } \\
\text { students }\end{array}$ & 1.951 .09 \\
\hline 11 & 18 & $\begin{array}{l}\text { I think that e-learning helps in disseminating technology in } \\
\text { society }\end{array}$ & 1.940 .87 \\
\hline 15 & 19 & $\begin{array}{l}\text { I think that there is a need to use e-learning in all the } \\
\text { educational stages }\end{array}$ & 1.900 .83 \\
\hline 27 & 20 & $\begin{array}{l}\text { I think that e-learning enables the students to learn a lot of } \\
\text { information in a short time }\end{array}$ & 1.900 .74 \\
\hline 20 & 21 & I tend to use e-learning applications in order to provide & 1.850 .89 \\
\hline
\end{tabular}


each student with the opportunity for learning according to his own speed / taking into account the individual differences reduce exposing the studentsto danger e-learning applications helps me instruct and guide the students in a better way

24 I think that the traditional teaching method gives better results than e-learning

25 I think that learning through e-learning can hinder his ability to think, imagine, and innovate

1626 I think that e-learning reduces the amount of appreciation of the teacher in front of his students teacher's responsibilities

2628 I think e-learning hinders my job as a teacher

Table 8 shows that the overall mean for the level of the attitudes of the science teachers towards using the e-learning applications in the domain of the strategies of e-learning was of (2.16) and a standard deviation of (0.49). if we compare this mean with the allocated score of (3), we will notice that the attitudes of teachers towards using the e-learning applications was negative.

This can be attributed to the lack of financial and morale motives in order to encourage teachers to use e-learning applications and this support comes by the financial rewards and by not imposing pressure on them to use the computer and at the same time informing them about the advantage that they and their students may gain from this. most teachers use e-learning applications as an educational system even though they aren't enthusiastic for e-learning in addition to the fact that many teachers experienced a conventional environment were teaching is centered on the teacher and then they moved to the university or the work life in which they continued to use conventional learning habits which are based on dictation. therefore, it is difficult for those individual to replace that with e-learning applications and with new styles of learning that depends on treating with new technology. this finding contradicts Al-Shonaq and BaniDomy 2010 where the results of their study showed that there are positive attitudes among the teachers towards e-learning.

3.1.4 the results relating to the third question and discussing them: the question is what are the obstacles of using E-learning applications in teaching science in Al-Tafila govern ate among the science teachers from their own point of view ?"

The means and the standard deviations were calculated for the respondents according to each domain in the study as well as the total domain and table 9 illustrates the results. 


\section{Macrothink}

Journal of Studies in Education

ISSN 2162-6952

2017, Vol. 7, No. 4

Table 9. the means and standard deviations for the degree of obstacles facing science teachers in using E-learning in Al-Tfila governorate

\begin{tabular}{cllccc}
\hline Rank & Domains & & mean & Standard deviation & level \\
\hline 1 & $\begin{array}{l}\text { Obstacles } \\
\text { teacher }\end{array}$ & relating & tc2.68 & 0.76 & Medium \\
2 & $\begin{array}{l}\text { Obstacles } \\
\text { E-learning } \\
3\end{array}$ & relating & to2.46 & 0.69 & Medium \\
4 & $\begin{array}{l}\text { Obstacles } \\
\text { students }\end{array}$ & relating & tc2.37 & 0.79 & Medium \\
Administrative & and2.12 & 0.84 & Low \\
technical obstacles & Total & 2.39 & 0.59 & Medium \\
\hline
\end{tabular}

Table (9) illustrates that the total means for the degree of obstacles facing teachers in using E-learning in Al-Tfila governorate was of a medium degree with a mean of (2.39) and a standard deviation of (0.59). as for the level of domains, the domain of Obstacles relating to teacher was in the first rank, with a mean of (2.46) and with a medium degree; the domain of Obstacles relating to E-learning was in the second rank, with a mean of (2.68) and with a medium degree; the domain of Obstacles relating to the student was in the third rank, with a mean of (2.37) and with a medium degree ; the domain of administrative and technical Obstacles was in the last rank, with a mean of (2.12) and with a low degree. Figure (2) illustrates the difference in the degrees of the obstacles of using E-learning applications among science teachers according to each domain in the study as well as the total domain

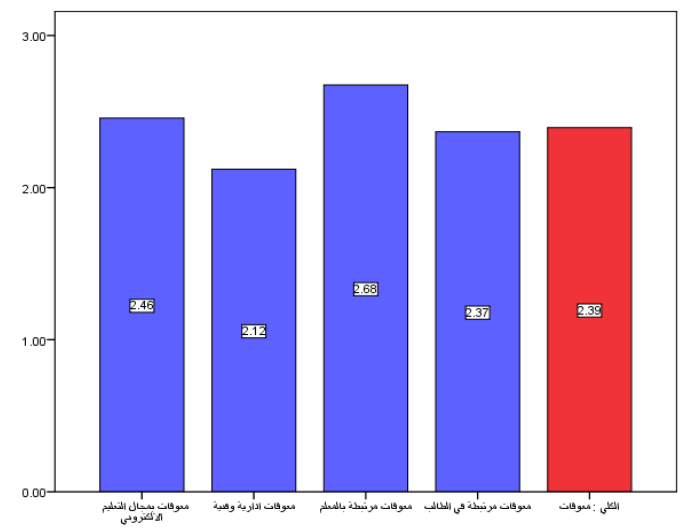

Figure 2. The difference in the estimation level for the obstacles of using E-learning applications among science teachers

And here is a detailed presentation for the obstacles of using E-learning applications among science teachers in Al-Tafila governorate from their perspective, and they are as follows:

Obstacles relating to E-learning: 
Table 10. the means and standard deviations for the obstacles relating to E-learning

\begin{tabular}{|c|c|c|c|c|c|}
\hline & Rank & The item content & mean & \multicolumn{2}{|c|}{$\begin{array}{l}\text { standard level } \\
\text { deviations }\end{array}$} \\
\hline 5 & 1 & $\begin{array}{l}\text { The lack of programs and electronic material } \\
\text { for Arabic curricula }\end{array}$ & 2.55 & 0.98 & Medium \\
\hline 3 & 2 & $\begin{array}{l}\text { The lack of specialists in designing the } \\
\text { educational materials in relation to E-learning }\end{array}$ & € 2.54 & 0.97 & Medium \\
\hline 1 & 3 & $\begin{array}{l}\text { Lack of availability of e-learning } \\
\text { applications in Arabic language }\end{array}$ & 2.49 & 1.00 & Medium \\
\hline 2 & 4 & The high cost of e-learning applications & 2.45 & 0.82 & Medium \\
\hline 6 & 5 & $\begin{array}{l}\text { The difficulty in accessing to modern } \\
\text { e-learning applications }\end{array}$ & 2.42 & 0.91 & Medium \\
\hline 4 & 6 & $\begin{array}{l}\text { The ambiguity of the philosophy and } \\
\text { objectives of e-learning }\end{array}$ & 2.40 & 0.90 & Medium \\
\hline 7 & 7 & $\begin{array}{l}\text { The frequent change or closing of the } \\
\text { websites }\end{array}$ & 2.35 & 1.00 & Medium \\
\hline- & - & & 2.46 & 0.69 & Medium \\
\hline
\end{tabular}

Table (10) illustrates that the total means for the degree of obstacles facing teachers in using E-learning in Al-Tafila governorate was of a medium degree with a mean of (2.46) and a standard deviation of (0.69), and all the items of this domain were with a medium degree.

This is attributed to the fact that designing the materials and the programs of E-learning require a high cost as well as a high consume of time, it also needs specialists who are experienced in designing the technology of teaching. therefore, this finding agrees with the results of (Al-Kasasbeh, 2012), where the average estimation for the obstacles relating to E-learning was of a medium degree.

2. the obstacles relating to the administrative and technical domains 
Table 11. the means and the standard deviations for the obstacles relating to the administrative and technical domains

\begin{tabular}{|c|c|c|c|c|c|}
\hline $\begin{array}{l}\text { Item } \\
\text { number }\end{array}$ & & kThe item content & mean & $\begin{array}{l}\text { standard } \\
\text { deviations }\end{array}$ & $\overline{\text { leve] }}$ \\
\hline 16 & 1 & The low speed of internet at schools & 2.42 & 1.06 & $\overline{\text { Low }}$ \\
\hline 8 & 2 & $\begin{array}{l}\text { The lack of the e-learning equipments and theit } \\
\text { inadequacy for using }\end{array}$ & 2.41 & 1.14 & low \\
\hline 10 & 3 & $\begin{array}{l}\text { The lack of the places that are supplied with the } \\
\text { proper E-learning equipments }\end{array}$ & 2.27 & 1.33 & low \\
\hline 9 & 4 & The lack of internet at schools & 2.21 & 1.16 & low \\
\hline 12 & 5 & $\begin{array}{l}\text { The lack of computer laboratories needed for the use } \\
\text { of teachers }\end{array}$ & 2.12 & 1.15 & low \\
\hline 17 & 6 & $\begin{array}{l}\text { The lack of educational programs for teaching } \\
\text { Science }\end{array}$ & 2.11 & 1.17 & low \\
\hline 13 & 7 & The lack of maintenance for the computer devices & 2.08 & 1.05 & low \\
\hline 14 & 8 & The increased number of students in the classes & 1.98 & 1.13 & Low \\
\hline 11 & 9 & $\begin{array}{l}\text { The prevalent educational system impedes using the } \\
\text { E-learning applications }\end{array}$ & 1.90 & 1.07 & Low \\
\hline 15 & 10 & $\begin{array}{l}\text { the e-learning lacks security and safety regarding the } \\
\text { exams' content }\end{array}$ & 1.71 & 1.00 & Low \\
\hline - & - & & 2.12 & 0.84 & low \\
\hline
\end{tabular}

Table (11) illustrates that the total means for the degree of obstacles facing teachers in using E-learning applications relating to the administrative and technical domains was of a low degree with a mean of (2.12) and a standard deviation of (0.84). the item (16) "the slow speed of internet at schools" was in the first rank with a mean of (2.42) and with a medium degree ; this may be attributed to the fact that the presented service needs a financial support which may not match with the school's budget, where the item 15 "the e-learning lacks security and safety regarding the exams' content" in the last rank with a mean of (1.71) and a low degree; this may be attributed to the teachers' awareness regarding the danger of this point as well the availability of many ways for protecting the data from being manipulated, and thus, it would contradict with (Al-Kasasbeh, 2012) where the overall estimation of the obstacles relating to the administrative and technical aspect was medium with a mean of (3.54)

- Obstacles relating to the teacher: 
Table 12. the means and the standard deviations for the obstacles relating to the teacher

\begin{tabular}{|c|c|c|c|c|c|}
\hline $\begin{array}{l}\text { Item } \\
\text { number }\end{array}$ & Rank & The item content & mean & $\begin{array}{l}\text { stand } \\
\text { devia }\end{array}$ & level \\
\hline 19 & 1 & $\begin{array}{l}\text { Not having a computer for the science } \\
\text { teacher at the school }\end{array}$ & 3.02 & 1.21 & Medium \\
\hline 21 & 2 & $\begin{array}{l}\text { The difficulty of making educational } \\
\text { materials by the teacher }\end{array}$ & 3.00 & 1.24 & Medium \\
\hline 20 & 3 & $\begin{array}{l}\text { Lack of Internet access in the teacher's } \\
\text { home }\end{array}$ & 2.98 & 1.29 & Medium \\
\hline 18 & 4 & $\begin{array}{l}\text { The weakness in teachers' skills regarding } \\
\text { using e-learning applications }\end{array}$ & 2.87 & 1.19 & Medium \\
\hline 26 & 5 & $\begin{array}{l}\text { The unwillingness of the teacher to } \\
\text { subscribe in the electronic sites because of } \\
\text { the financial cost }\end{array}$ & 2.63 & 1.19 & Medium \\
\hline 24 & 6 & $\begin{array}{l}\text { The unwillingness of science teachers to } \\
\text { attend computer courses }\end{array}$ & 2.56 & 0.87 & Medium \\
\hline 25 & 7 & $\begin{array}{l}\text { Lack of a computer specialist in order to } \\
\text { assist the science teacher }\end{array}$ & 2.54 & 1.13 & Medium \\
\hline 23 & 8 & $\begin{array}{l}\text { the teacher's poor skills in using science } \\
\text { education websites }\end{array}$ & 2.42 & 1.05 & Medium \\
\hline 22 & 9 & $\begin{array}{l}\text { The teacher is not satisfied with using } \\
\text { computers in teaching science }\end{array}$ & 2.06 & 1.16 & Low \\
\hline- & - & Total & 2.68 & 0.76 & Medium \\
\hline
\end{tabular}

Table (12) illustrates that the total means for the degree of obstacles facing teachers in using E-learning applications relating to the domain of teacher was of a medium degree with a mean of (2.68) and a standard deviation of (0.76). the item (19) "Not having a computer for the science teacher at the school" was in the first rank with a mean of (3.02) and with a medium degree, where the item 22 "The teacher is not satisfied with using computers in teaching science" was in the last rank with a mean of (2.06) and a low degree; this may be attributed to the unavailability of computers, laboratories as well as internet which led to no using the e-learning applications in teaching, and thus, it would agree with (Al-Kasasbeh, 2012) where the overall estimation of the obstacles relating to the domain of teacher were medium, while it contradicts with (Shamout, 2008), as the obstacles relating to the domain of teacher was high.

This may be attributed to the low financial support allocated to schools as well as the high prices of computers and the increased numbers of teachers at schools.

- Obstacles relating to the student: 
Table 13. the means and the standard deviations for the obstacles relating to the student

\begin{tabular}{|c|c|c|c|c|c|}
\hline $\begin{array}{l}\text { Item } \\
\text { number }\end{array}$ & Rank & The item content & mean & $\begin{array}{l}\text { stand } \\
\text { devia }\end{array}$ & level \\
\hline 28 & 1 & $\begin{array}{l}\text { The weakness of students in English } \\
\text { reduces the use of English-language } \\
\text { applications }\end{array}$ & 3.34 & 1.08 & Medium \\
\hline 32 & 2 & $\begin{array}{l}\text { Students tend to research inappropriate } \\
\text { websites during learning }\end{array}$ & 2.42 & 1.15 & Medium \\
\hline 33 & 3 & $\begin{array}{l}\text { The students lack the skills of using } \\
\text { e-learning applications }\end{array}$ & 2.34 & 1.16 & Medium \\
\hline 31 & 4 & $\begin{array}{l}\text { The students are not serious about dealing } \\
\text { with e-learning applications }\end{array}$ & 2.32 & 1.07 & Low \\
\hline 30 & 5 & $\begin{array}{l}\text { Some students do not have a computer at } \\
\text { home }\end{array}$ & 2.22 & 1.03 & Low \\
\hline 34 & 6 & Lack of Internet skills & 2.14 & 1.06 & Low \\
\hline 29 & 7 & $\begin{array}{l}\text { Lack of Internet access in the student's } \\
\text { home }\end{array}$ & 2.10 & 1.13 & Low \\
\hline 27 & 8 & Students fear of using computers & 2.05 & 1.08 & Low \\
\hline- & - & Total & 2.37 & 0.79 & Medium \\
\hline
\end{tabular}

Table (13) illustrates that the total means for the degree of obstacles facing teachers in using E-learning applications relating to the domain of teacher was of a medium degree with a mean of (2.37) and a standard deviation of (0.79). the item (28) "The weakness of students in English reduces the use of English-language applications" was in the first rank with a mean of (3.34) and with a medium degree, where the item 27 "Students fear of using computers" was in the last rank with a mean of (2.05) and a low degree; and thus, it would contradict with (Shamout, 2008), as the obstacles relating to the domain of students were of a high degree and it also contradicts with (Al-Kasasbeh, 2012), where the mean was high too; this may be attributed to the high financial cost of buying a computer in the student's home, and the students poor skills in English language, in addition to the existence of many insecure websites that students may watch during learning.

In general, the obstacles listed in table (10) were ranked as follows, first, obstacles related to the teacher; second, obstacles related to e-learning; third obstacles related to the student; and finally, obstacles related to administrative and technical domains. As a result, the finding agree with Al-Kandari, Al-Rashidi, and Abdul-Rahim, 2011), where the obstacles in the study were the human obstacles in the first place, the financial obstacles in the second place, and the natural obstacles in the last place.

4.1.4 The results relating to the fourth question "does the degree at which the science teachers use the e-learning applications differ by gender, experience and educational qualification ?" and discussing them. 
The mean and standard deviations were calculated for the estimates of science teachers in Al-Tafila governorate regarding the extent of using e-learning applications according to the variables of the study (gender, experience, educational qualification). Table (14) illustrates that.

Table 14. the means and the standard deviations for degree at which the science teachers use the e-learning according to the study variables

\begin{tabular}{llcc}
\hline Variable & Variable categories & Mean & Standard deviation \\
\hline \multirow{2}{*}{$\begin{array}{l}\text { Educational } \\
\text { qualification }\end{array}$} & Diploma & 3.39 & 0.53 \\
& Bachelor & 3.57 & 0.85 \\
& Higher studies & 3.55 & 0.65 \\
Experience & Total & 3.56 & 0.82 \\
& Less than 3 yeas & 3.68 & 1.03 \\
& 5-10 years & 3.46 & 0.78 \\
& More than 10 & 3.59 & 0.69 \\
& years & & \\
& total & 3.56 & 0.82 \\
Gender & Male & 3.61 & 0.85 \\
& Female & 3.52 & 0.78 \\
& total & 3.56 & 0.82 \\
\hline
\end{tabular}

The data presented in table (14) illustrate that there are apparent differences in the mean of the science teachers' estimations in Al-Tafila governorate regarding the degree at which they use E-learning applications according to the study variables (gender, experience, academic qualification) and to reveal whether these differences are statistically significant, the Multiple-ANOVA analysis was used, and Table (15) illustrates the results. 


\section{Mll Macrothink}

Journal of Studies in Education

ISSN 2162-6952

2017, Vol. 7, No. 4

Table 15. the results of the multiple variance analysis to detect the differences in the estimates of science teachers regarding the degree at which they use e-learning applications according to the study variables:

\begin{tabular}{llllll}
\hline $\begin{array}{l}\text { The source of } \\
\text { variance }\end{array}$ & Squares total & $\begin{array}{l}\text { Degree } \\
\text { of freedom }\end{array}$ & Mean squares F-value & Level of significance \\
\hline Gender & 0.096 & 1 & 0.096 & 0.154 & 0.695 \\
Qualification & 0.655 & 2 & 0.328 & 0.524 & 0.593 \\
Experience & 0.983 & 2 & 0.491 & 0.785 & 0.458 \\
Gender*qualification & 1.822 & 2 & 0.911 & 1.456 & 0.236 \\
Gender*experience & 1.612 & 2 & 0.806 & 1.289 & 0.278 \\
Qualification*experience & 1.472 & 4 & 0.368 & 0.589 & 0.671 \\
Gender* & 1.916 & 2 & 0.958 & 1.532 & 0.219 \\
qualification*experience & & & & & \\
Error & 100.694 & 161 & 0.625 & & \\
Total & 2360.712 & 177 & & & \\
\hline
\end{tabular}

The data presented in table (15) show that there are no statistically significant differences at the level of $(\alpha \leq 0.05)$ regarding the estimates of science teachers in Al-Tafila governorate to the extent at which they use e-learning applications according to the variables of the study (gender, experience, academic qualification) as well as the interaction between them.

This finding may be attributed to the fact that all teachers undergo similar training programs regardless of their academic qualification, and that is similar to the methods used at universities. Teachers, regardless of their qualifications, deal with the same e-learning applications, study the same curricula and attend the same training courses, and that there is a large range of similarity between all teachers in terms of their educational qualification and the main difference between them is in the study of specialization courses. Furthermore, teachers experience the same educational conditions at schools which, in turn, leads to common aspects between the different scientific qualifications. Therefore, this result agree with the study of (Al-Amayreh, 2003), where the results of the study showed that there are no statistically significant differences regarding the effect of variables on the degree of teachers' use of teaching techniques in the educational process.

5.1.4 The results relating to the fifth question "do the obstacles of science teachers usage of the e-learning applications differ by gender, experience and educational qualification ?"and discussing them.

The mean and standard deviations were calculated for the estimates of science teachers in Al-Tafila governorate regarding the obstacles that prevent applying e-learning applications according to the variables of the study (gender, experience, educational qualification). Table (16) illustrates that. 
Table 16. the means and the standard deviations regarding the obstacles that prevent applying e-learning applications according to the variables of the study (gender, experience, educational qualification

\begin{tabular}{|c|c|c|c|}
\hline Variable & Variable categories & Mean & Standard deviation \\
\hline & Diploma & 2.17 & 0.19 \\
\hline \multirow{3}{*}{$\begin{array}{l}\text { Educational } \\
\text { qualification }\end{array}$} & Bachelor & 2.39 & 0.61 \\
\hline & Higher studies & 2.48 & 0.53 \\
\hline & Total & 2.40 & 0.59 \\
\hline \multirow[t]{5}{*}{ Experience } & Less than 3 yeas & 2.59 & 0.47 \\
\hline & $5-10$ years & 2.29 & 0.66 \\
\hline & $\begin{array}{l}\text { More than } 10 \\
\text { years }\end{array}$ & 2.39 & 0.56 \\
\hline & total & 2.40 & 0.59 \\
\hline & Male & 2.40 & 0.66 \\
\hline \multirow[t]{2}{*}{ Gender } & Female & 2.39 & 0.52 \\
\hline & total & 2.40 & 0.59 \\
\hline
\end{tabular}

The data presented in table (16) illustrate that there are apparent differences in the mean of the science teachers' estimations in Al-Tafila governorate regarding the obstacles that prevent them from using E-learning applications according to the study variables (gender, experience, academic qualification) and to reveal whether these differences are statistically significant, the Multiple-ANOVA analysis was used, and Table (17) illustrates the results. 
Table 17. the results of the multiple variance analysis to detect the differences in the estimates of science teachers regarding the obstacles that prevent them from using E-learning applications according to the study variables:

\begin{tabular}{llllll}
\hline $\begin{array}{l}\text { The source of } \\
\text { variance }\end{array}$ & $\begin{array}{l}\text { Squares } \\
\text { total }\end{array}$ & $\begin{array}{l}\text { Degree } \\
\text { of } \\
\text { freedom }\end{array}$ & $\begin{array}{l}\text { Mean } \\
\text { squares }\end{array}$ & F-value & Level of significance \\
\hline Gender & 0.081 & 1 & 0.081 & 0.242 & 0.623 \\
Qualification & 1.056 & 2 & 0.528 & 1.575 & 0.210 \\
Experience & 1.780 & 2 & 0.890 & 2.655 & 0.073 \\
Gender*qualification & 0.168 & 2 & 0.084 & 0.251 & 0.778 \\
Gender*experience & 3.300 & 2 & 1.650 & 4.922 & $* 0.010$ \\
Qualification*experience & 1.555 & 4 & 0.389 & 1.160 & 0.331 \\
Gender* & 1.790 & 2 & 0.895 & 2.671 & 0.072 \\
qualification*experience & & & & & \\
Error & 53.961 & 161 & 0.335 & & \\
Total & 1076.833 & 177 & & &
\end{tabular}

* Statistically significant at the level of significance $(\alpha \leq 0.05)$

The data presented in table (17) show that there are no statistically significant differences at the level of $(\alpha \leq 0.05)$ regarding the estimates of science teachers in Al-Tafila governorate about the obstacles that prevent using e-learning applications according to the variables of the study (gender, experience, academic qualification) as well as the interaction between Gender*qualification, Qualification*experience, Gender* qualification*experience, while the results showed that there are differences in the interaction between (Gender*experience), and figure (3) illustrates the interaction between them. This result may be attributed to the agreement among the various perspectives of the male and female science teachers in the Directorate of Education of Al-Tafila that these obstacles are reality from which the science teacher suffers, regardless his gender, either male or female. This finding may demonstrate that the difficulties of teaching science using the e-learning applications are observed and experienced by male and female teachers, either they have a diploma degree, a bachelor's degree or a postgraduate degree.

As for the variable of gender, the data presented in table (17) show that there are no statistically significant differences at the level of $(\alpha \leq 0.05)$ regarding the estimates of science teachers in Al-Tafila governorate about the obstacles that prevent using e-learning applications according to the variable of gender. This result may be attributed to the fact that the male and female teachers take the same training courses and they work at schools with similar in terms of systems, financial and technical potentials ; furthermore, those teachers 
studied in the same universities which means that they took lectures in the same way, and so it was observed that they use the e-learning applications in the same level and degree. This finding agreed with (Al-Kasasbeh, 2012) which showed that there are no statistically significant differences in the extent at which the science teachers in Al-Karakdirectorate use the E-learning applications in teaching science due to the variable of gender, and also agreed with (Al-Amayreh, 2003) which showed that there are no statistically significant differences for the impact of gender regarding using the E-learning applications in teaching, while this finding contradicted with (Murad, 2014) which showed that there are morale differences regarding the obstacles of using information and communication technology in teaching in favor of the male teachers.

As for the variable of academic qualification, the data presented in table (17) show that there are no statistically significant differences at the level of $(\alpha \leq 0.05)$ regarding the estimates of science teachers in Al-Tafila governorate about the obstacles that prevent using e-learning applications according to the variable of academic qualification. This result may be attributed to the fact that the male and female teachers take similar training programs regardless their academic qualification, and there is also a similarity in the styles used in the colleges and universities and that teachers regardless their academic qualification deal with the same E-learning applications and teach similar scientific curricula, they also attend the same training courses during service. Furthermore, teachers experience the same educational condition inside the school, which makes a common case of familiarity between the various academic qualifications. This finding agreed with (Al-Kasasbeh, 2012) which showed that there are no statistically significant differences in the extent at which the science teachers in Al-Karak directorate use the E-learning applications in teaching science due to the variable of academic qualification.

As for the variable of teaching experience, the data presented in table (17) show that there are no statistically significant differences at the level of $(\alpha \leq 0.05)$ regarding the estimates of science teachers in Al-Tafila governorate about the obstacles that prevent using e-learning applications according to the variable of teaching experience. This result may be attributed to the fact that most male and female teachers experience in teaching is relatively new, some of them have passed the course of ICDL and some others will attempt to gain it, since the Ministry of Education required that all the teachers should take as well as other courses such as Intel, the modernity of using the E-learning applications in schools make those who have long experience and those who have short experience in teaching equal in its use. The use of e-learning applications does not require teaching experience as much as it requires the training about the ways using it. This finding agreed with (al-Amayreh, 2003) and (Al-Kasasbeh, 2012). 


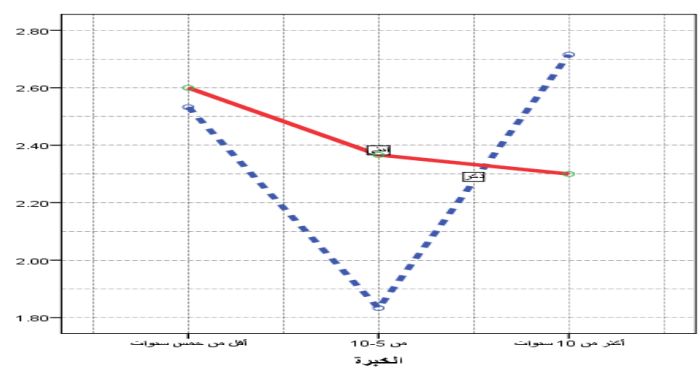

$= \pm$

Figure 3.

The differences in the estimates of the science teachers for the obstacles of applying the E-learning according to the interaction between (Gender*experience)

The results of figure (3) show that the estimates of the females with short and medium teaching experience(Less than 5years and 5-10 years) outweigh the male estimates for the obstacles of using e-learning in science teaching, but with the increased experience for females (over 10 years), their estimates for obstacles are lower than those of male teachers.

2.4 recommendations:

Based on the results of the current study about the reality using e-learning applications among science teachers in teaching science in Al-Tafila governorate, the researcher recommends about the following:

- Recruiting experienced or technicians in the field of technological techniques in order to help the teachers and facilitating their tasks.

- $\quad$ Providing the teachers and schools with new and sufficient computer devices.

- Holding training courses for the teachers in order to acquire the skills of using the E-learning applications as well as designing the programs of E-learning.

- Conducting workshops and seminars to educate the teachers about the importance of using the E-learning applications.

- $\quad$ Conducting a study about the reality of the science teachers usage for the E-learning from the headmasters, students and supervisors perspectives.

- Conducting a study similar to the current one by using other tools such as the

- $\quad$ note cards.

\section{References}

Sabitan, Fatehi Thiab (2010). The Principles and methods of teaching science. Jordan, Amman: Al-Junadriyah Press for Publishing and Distribution.

Sa'dah, Jawdat \& Al-Sartawi, Adel. (2007). Using computer and Internet. Jordan, Amman: Al Shorouq Press for Publishing and Distribution. 
Al-Shater, Azhar. (2007). The attitudes of Mathematics Teachers of the Basic Stage in the Second Education Directorate of Amman Towards Electronic Learning. Unpublished Master Thesis, The University of Jordan, Jordan.

Al-Shonnaq, Kassim, \& BaniDomi, Hassan. (2009). The basics of e-learning in science. Jordan, Amman: Wa'el Press for Publishing and Distribution.

Al-Shonnaq, Kassim, \& BaniDomi, Hassan (2009). the attitudes of teachers and students towards using E-learning, the University of Damascus. Damascus, 26(241), 235-270.

Al-Shahry, Fayez bin Abdullah. (2002). E-learning in Saudi schools the journal of Knowledge, 36(91), 36-43.

AbdulHameed, Abdel Aziz Toulba. (2010.) E-Learning and The Modernization of Educational Technology, Al- Mansoura, Egypt: the modern Library for Publishing and Distribution.

Abdulmajeed, Huthaifah, \& Alani, Moziher. (2015). Interactive e-learning. Jordan, Amman: the academic book center.

Al-Obaid, Afnan. (2011). A model application for the collaborative learning ....Using Wiki. The journal of Knowledge. Http://almarefh.net/show_content_sub.php?CUV=386\&Model=M\&SubModel=135\&ID=116 4\&ShowAll=OnReturned 18/6/2016 3:55 pm

Al-Amayreh, Mohammad. (2003). The perspectives of teachers of some international relief agency schools in Jordan about the importance of using educational techniques and the difficulties they face in using them. the Journal of Educational and Psychological Sciences, Bahrain, 4(4), 133-164.

Ayyash, Amal \& Al-Safi, Abdul Hameed. (2007). The methods of teaching science for the basic stage. Amman, Jordan: Al Fikr press for Publishing and Distribution.

Al-Ghorab, Eiman. (2007). E-Learning “An Introduction to Non-Traditional Training". The Arab Organization for Administrative Development.

Gholloum, Mansour. (2003). E - learning in schools of the Ministry of Education in Kuwait. A work sheet presented to the e-learning seminar, King Faisal Schools, Al-Riyadh. 2123/2003.

GhonaymMohany Mohammad. (2006). The philosophy of e-learning and its socio-economic feasibility in the light of moral responsibility and legal accountability. Research paper presented to the E-learning conference: a new bag in learning and culture. E - Learning Center, The University of Bahrain 17 - 19 April, 2006.

Al-Farra, Yahya. (2003). E-learning: insights from the field. The first international E-learning seminar that is held in King Faisal schools in Al- Riyadh. The Ministry of Education, The General Directorate of Education Makkah Al-Mukarramah - Jeddah.

Qotait, Ghassan. (2011). The Computerization of Teaching. Jordan, Amman: The House of Culture. 


\section{Macrothink}

Qotait, Ghassan. (2015). Modern learning and teaching techniques. Jordan, Amman: The House of Culture for Publishing and Distribution.

Al-kasasbeh, Tariq Yassin. (2012). The extent at which science teachers use the e-learning applications in science teaching and the obstacles of using them in the schools of Al-Karak educational districts unpublished master thesis, Mu'tah University, Jordan.

Al-Kindari, Waleed \& Al-Rashidi, Fahad and Abdul Raheem, Abdul Raheem. (2011). The Obstacles of applyingthe E-learning in the State of Kuwait. Al-Yarmouk Researches. Human and Social Sciences, 27(3), 2029-2054.

Murad, Awdeh. (2014). The Use of Information and Communication Technologies and the obstaclesof using them in teaching among the male and female teachers in the Schools of Al-Shoubak / Jordan. Al-Balqa for Researches and Studies, 17(1), 107-138.

Al-Mohaisen, Ibrahim. (2002). E-learning.... a luxury or a necessity...?! A work paper presented to the Future School Seminar, 16-17 / 1423H, King Soud University.

Al-Mousawi, Ala' Bin Mohammad. (2008). The Requirements for activating E-learning. A work paper presented to the first E-learning forum, The University of Bahrain, May 2008.

Al-Na'washi, Qassim. (2010). The world in the classroom usingInformation and Communication Technologies in education. Jordan, Amman: Wa'elPress for Publishing and Distribution.

The foreign references:

Buck, H \& Horton, Ph. (1996). who's using what and how often: An assessment of the use of instruction technology in the classroom. Journal of Education Research, 36, 7-60.

Hudson, R, Porter, A. \& Nelson, M. (2008). Barriers to Using ICT in Mathematics Teaching Issues in Methodology Avaible on: ro.uow.edu.au/cgi/viewcontent.cgi?article=2392\&context $=$ infopapersretrened on 2015,21:07/12/7

Parker, Randal. (1997). Increasing Faculty use of Technology in teaching and teacher education. Journal of Technologyand Teacher Education USA, 5,105-115.

Rowand,Cassandra. (1999). Teachers of computers and the Internet in publx school "NCES.U.S. Department of Education Washington,Ds:National Center For Education Statistics.

Shu,H, Siu, M. \& Gwo,D.(2006). Surveying Instruction and Learner Perception of E-learning. Journal of Educational Technology, 53(5), 622-275. 